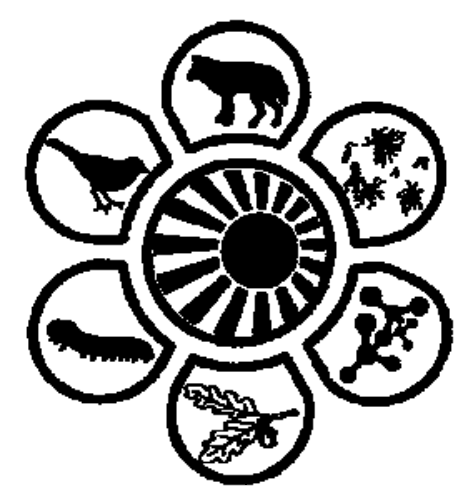

Вісник Дніпропетровського університету. Біологія, екологія.

Vìsnik Dnìpropetrovs'kogo unìversitetu. Seriâ Bìologiâ, ekologiâ

Visnyk of Dnipropetrovsk University. Biology, ecology.

Vìsn. Dnìpropetr. Unìv. Ser. Bìol. Ekol. 2016. 24(1), 182-187.

doi: $10.15421 / 011622$

ISSN 2310-0842 print

ISSN 2312-301X online

www.ecology.dp.ua

UDC 638.1:577.115:574

\title{
Fatty acid content of honeycombs depending on the level of technogenic loading on the environment
}

\author{
V.Y. Vishchur ${ }^{1}$, I.I. Saranchuk ${ }^{2}$, B.V. Gutiy ${ }^{3}$ \\ ${ }^{1}$ Institute of Animal Biology of NAAS, Lviv, Ukraine \\ ${ }^{2}$ Bukovyna State Agricultural Experimental Station of NAAS, Chernivtsi, Ukraine \\ ${ }^{3}$ Lviv National University of Veterinary Medicine and Biotechnologies named after S.Z. Gzhytskyj, Lviv, Ukraine
}

\begin{abstract}
The content of heavy metals, non-etherified and anionic forms of fatty acids, and also fatty acids of common lipids in honeycomb cells, obtained from hives placed in areas with high, medium and low levels of technogenic loading is investigated. The hives were located at the educational apiary of Lviv National University of Veterinary Medicine and Biotechnologies named after S.Z. Gzhytskyj (area with very heavy traffic and industrial activity) and in private beekeeping farms in the town Vynnyky and the village Chyzhyky, Pustomyty district, Lviv region (areas with lower intensity of traffic and industrial activity). Our research has shown that the newly-built honeycomb cells obtained from hives placed in the territory with medium and low levels of technogenic loading contain a lower quantity of such heavy metals as iron, zinc, cuprum, chromium, nickel, lead and cadmium. The total amount of non-etherified fatty acids with even and odd number of carbon atoms in the chain, monounsaturated fatty acids of n-7 and n-9 families and polyunsaturated fatty acids of n-3 and n-6 families was higher in these honeycombs. However, the total concentration of anionic forms of fatty acids with even and odd number of carbon atoms in the chain, monounsaturated fatty acids of n-7 and n-9 families and polyunsaturated fatty acids of n-3 and n-6 families was lower in these honeycombs. Due to the above-mentioned monounsaturated and polyunsaturated fatty acids the amount of fatty acids of common lipids rises. It leads to increase in the antibacterial and antifungal properties of honeycomb cells and reduction of fragility of their walls. The greatest changes in concentration of heavy metals, non-etherified and anionic form of fatty acids, and also fatty acids of common lipids occur in the newly built honeycomb cells in the territory with low technogenic loading on the environment.
\end{abstract}

Keywords: beehives; heavy metals; fatty acids

\section{Жирнокислотний склад бджолиних стільників залежно від рівня техногенного навантаження на довкілля}

\author{
В.Я. Віщур ${ }^{1}$, І.І. Саранчук², Б.В. Гутий ${ }^{3}$ \\ ${ }^{1}$ Інститут біологї̈ тварин НААН, Львів, Украӥна \\ ${ }^{2}$ Буковинська державна сільськогосподарська дослідна станиія НААН, Чернівиі, Україна \\ $3^{3}$ Львівський національний університет ветеринарної медицини та біотехнологій імені С.З. Гжицького, \\ Львів, Украӥна
}

Досліджено вміст важких металів, неетерифікованих і аніонних форм жирних кислот, а також жирних кислот загальних ліпідів у бджолиних стільниках, які отримано з вуликів, розміщених на територіях із високим, середнім та низьким рівнем техногенного навантаження. Проби відібрано на навчальній пасіці (територія 3 дуже інтенсивним рухом транспорту та роботи промислових підприємств) та у приватних пасічних господарствах (території з меншою інтенсивністю руху транспорту та роботи промислових

Інститут біології тварин НААН, вул. В. Стуса, 38, Львів, 79034, Украӥна

Institute of Animal Biology of NAAS, V. Stus Str., 38, Lviv, 79034, Ukraine

Tel.: +38-097-747-61-25. E-mail:v.vishchur@gmail.com

Буковинська державна сільськогосподарська дослідна станиія НААН, вул. Кузнеиова, 21а, Чернівиі, 58026, Україна Bukovyna State Agricultural Experimental Station of NAAS, Kuznetsova Str., 21a, Chernivtsi, 58026, Ukraine

Львівський національний університет ветеринарної медицини та біотехнологій імені С.3. Гюицького, вул. Пекарська, 50, Львів, Україна Lviv National University of Veterinary Medicine and Biotechnologies named after S.Z. Gzhytskyj, Pekarska Str., 50, Lviv, Ukraine 
підприємств). У свіжопобудованих бджолиних стільниках, які отримано з вуликів, розміщених на території із середнім та низьким рівнями техногенного навантаження, міститься менша кількість феруму, цинку, купруму, хрому, нікелю, плюмбуму та кадмію. У цих стільниках вищий загальний вміст неетерифікованих форм насичених жирних кислот із парною та непарною кількістю вуглецевих атомів у ланцюгу, мононенасичених жирних кислот родин n-7 i n-9 i поліненасичених жирних кислот родин n-3 i n-6. Натомість у них менша загальна концентрація аніонних форм насичених жирних кислот із парною та непарною кількістю вуглецевих атомів у ланцюгу, мононенасичених жирних кислот родин n-7 i n-9 і поліненасичених жирних кислот родин n-3 i n-6. За рахунок наведених вище мононенасичених і поліненасичених жирних кислот у них зростає кількість жирних кислот загальних ліпідів. Це зумовлює підвищення антибактеріальної та антигрибкової активності бджолиних стільників і зменшення крихкості їх стінок. Найбільше змінюється концентрація важких металів, неетерифікованих і аніонних форм жирних кислот, а також жирних кислот загальних ліпідів у свіжопобудованих бджолиних стільниках на території з низьким рівнем техногенного навантаження.

Ключові слова: вулики; важкі метали; жирні кислоти

\section{Introduction}

Intensive development of the chemical industry and agriculture, environmental degradation and pollution by heavy metals causes growth of toxic lesions in humans and animals. One feature of heavy metals is that in small amounts almost all of them are necessary for plants and organisms (Kulbachko et al., 2011; Brygadyrenko and Ivanyshyn, 2014, 2015; Tsvetkova et al., 2016). However, when the permissible amount of these metals is exceeded this leads to serious diseases. Some heavy metals (mercury, cadmium, lead) are distinguished by a special feature of toxicity (Vymazal and Březinová, 2016). The development of industry, agriculture, energy and transport, intensive mining all lead to an increase of the concentrations of heavy metals in the air, water, soil, plants and plant pollen (Conti and Botrè, 2001; Wang Haiyan and Arne, 2003; Pashayan, 2006; Vikram Reddy et al., 2013). Thus, heavy metals are rapidly accumulated in the tissues of honey bees and honeycombs (Bogdanov, 2006; Perugini et al., 2011).

On the other hand, fatty acids are a vital component of food for honeybees (Saranchuk, 2013). In particular, the fatty acid composition of pollen affects the productive and reproductive characteristics of honeybees (Loidl and Crailsheim, 2001; Tan et al., 2015). In addition, fatty acids are the basic building blocks of honeycombs (Buchwald et al., 2009). There they are mostly linked to long-chain alcohols. Fatty acids in bee combs also occur in free (nonetherified) and bound condition with heavy metals (anionic) (Kononskyy, 2006). Thus, the fatty acid and mineral composition of honeycombs is an indicator of the ecological environment.

Having considered the given above, theoretical and practical interest lies in the study of heavy metals, anionic and nonetherified fatty acids and fatty common lipid content in honeycombs, depending on the level of environmental impact. The aim of the study was to find out the contents of heavy metals, anionic and nonetherified fatty acids and common fatty lipids in honeycombs, depending on the level of the technogenic load on the environment.

\section{Material and methods}

The level of environmental impact was determined by the content of heavy metals (iron, zinc, copper, chromium, nickel, lead, arsenic and cadmium) in the pollen of dandelions (Taraxacum officinale Wigg.). Samples of pollen from dandelions and freshly built honeycombs for laboratory tests were taken in apiaries located in areas with different intensities of traffic and industry. The hives studied were located at the training apiary of Lviv National University of
Veterinary Medicine and Biotechnologies named after S.Z. Gzhytsky (an area with very heavy traffic and industrial activity) and private beekeeping farms in Vynnyky town and Chyzhykiv village in Pustomiti district Lviv region (areas with lower intensity of traffic and industry). The private beekeeping farms in Vynnyky town and Chyzhykiv village are located at a distance of 2-3 and 5-6 km from the training apiary of Lviv National University of Veterinary Medicine and Biotechnologies named after S.Z. Gzhytsky. Moreover, both the training apiary of Lviv National University of Veterinary Medicine and Biotechnologies named after S.Z. Gzhytsky and the private beekeeping farms in Vynnyky and Chyzhykiv of Pustomiti district Lviv region are located along the Lviv - Ternopil highway.

In each of the above-mentioned areas samples of the pollen of dandelions and newly built honeycombs were selected, and in each apiary the samples of dandelion pollen and newly built honeycombs were taken from three hives. To identify the species of the dandelion pollen an identification study was performed using the computer programs Lucia (Laboratory Colour Image Analysis) and Pollen Data Bank.

In the selected samples of the bee pollen heavy metals were found and measured. In the selected samples of newly built honeycombs the concentrations of heavy metals, anionic and nonetherified fatty acids and fatty acids of total lipids was measured. The content of heavy metals in the studied biological material was measured on an atomic absorption spectrophotometer C-115 PC (Khavezov and Tsalev, 1983). The concentrations of anionic and nonetherified fatty acids and fatty acids of total lipids in the studied biological material were measured by the gas-liquid chromatography (Rivis and Fedoruk, 2010).

Mathematical processing of research results was conducted statistically using the software package Statistica 6.0. The results of the average values considered statistically significant at $\mathrm{P}<0.05, \mathrm{P}<0.01$ and $\mathrm{P}<0.001$ (ANOVA).

\section{Results and discussion}

It is ascertained that in the honeycombs, obtained from beehives located in areas with medium and low technogenic loading, compared with the honeycombs, selected from hives that are kept in a high level of anthropogenic impact the level of iron, zinc, copper, chromium, nickel, lead and cadmium is likely to be reduced (Table 1). Thus the content of the abovementioned heavy metals in honeycombs characterizes the degree of contamination of the studied areas. At the same time, in the honeycombs obtained from the beehives located in areas with high, medium and low technogenic impact on 
the environment, the content of nonetherified and anionic forms of fatty acids and fatty acids of total lipids is different, which affects their physical properties, antibacterial and antifungal activity (Bogdanov, 2003; Bogdanov et al., 2003).

Concentration of heavy metals in honeycombs (mg/kg natural mass, $M \pm \mathbf{m}, \mathbf{n}=\mathbf{3})$

\begin{tabular}{|l|c|c|c|}
\hline \multirow{2}{*}{$\begin{array}{c}\text { Heavy metals } \\
\text { and their symbol }\end{array}$} & high & Level of technogenic loading on the environment \\
\cline { 2 - 4 } & $85,2 \pm 3,42$ & $35,9 \pm 1,78^{* * *}$ & low \\
\hline Iron, $\mathrm{Fe}$ & $7,9 \pm 0,35$ & $3,8 \pm 0,17^{* * *}$ & $22,8 \pm 1,43^{* * *}$ \\
\hline Zinc, $\mathrm{Zn}$ & $0,14 \pm 0,009$ & $0,09 \pm 0,006^{* *}$ & $2,6 \pm 0,16^{* * *}$ \\
\hline Copper, $\mathrm{Cu}$ & $1,26 \pm 0,040$ & $1,06 \pm 0,058^{*}$ & $0,07 \pm 0,006^{* * *}$ \\
\hline Chromium, $\mathrm{Cr}$ & $0,67 \pm 0,032$ & $0,50 \pm 0,023^{* *}$ & $0,93 \pm 0,040^{* *}$ \\
\hline Nickel, $\mathrm{Ni}$ & $0,91 \pm 0,037$ & $0,68 \pm 0,032^{* *}$ & $0,41 \pm 0,023^{* * *}$ \\
\hline Lead, $\mathrm{Pb}$ & $0,06 \pm 0,006$ & $0,04 \pm 0,003^{*}$ & $0,45 \pm 0,020^{* * *}$ \\
\hline Cadmium, $\mathrm{Cd}$ & & & $0,03 \pm 0,006^{*}$ \\
\hline
\end{tabular}

Note: here and after * $-\mathrm{P}<0.05, * *-\mathrm{P}<0.01, * * *-\mathrm{P}<0.001$.

We found out that the level of the technologenic impact on the environment affects the overall content of nonetherified forms of fatty acids in honeybee combs. Thus, the total content of nonetherified forms of fatty acids in honeybee combs which were taken from the beehives located in the areas with medium and low levels of technogenic loading is higher than in the honeycombs which were taken from beehives located in the areas with high anthropogenic loading (Table 2). The highest content of nonetherified forms of fatty acids was found in bee combs received from the beehives located in areas of low technogenic loading.
The higher number of nonetherified forms of unsaturated fatty acids in honeycombs obtained from the beehives located in the areas with medium and low technogenic loading, in comparison with the honeycombs obtained from the beehives located in the areas with high anthropogenic impact can be explained mainly due to a higher content of monounsaturated fatty acids families n-7 and n-9 fatty acids and families of n-3 and $n-6$ in their composition. The ratio of nonetherified forms of polyunsaturated fatty acids of n-3 family to nonetherified form of polyunsaturated fatty acids of $n-6$ family is lower (Table 2). It is obvious that the above-mentioned processes take place in the wax glands of honey bees.

Table 2

Concentration of nonetherified forms of fatty acids in honeycombs $(\mathrm{mg} / \mathrm{kg}$ natural mass, $\mathrm{M} \pm \mathbf{m}, \mathbf{n}=\mathbf{3})$

\begin{tabular}{|l|c|c|c|}
\hline \multirow{2}{*}{ Fatty acids and their code number } & \multicolumn{3}{|c|}{ Level of technogenic loading on the environment } \\
\cline { 2 - 4 } & high & middle & low \\
\hline Caprylic, $8: 0$ & $0,58 \pm 0,026$ & $0,48 \pm 0,023^{*}$ & $0,46 \pm 0,023^{*}$ \\
\hline Capric, $10: 0$ & $0,24 \pm 0,011$ & $0,17 \pm 0,014^{* *}$ & $0,15 \pm 0,011^{*}$ \\
\hline Lauric, 12:0 & $0,29 \pm 0,014$ & $0,23 \pm 0,014^{*}$ & $0,20 \pm 0,012^{* *}$ \\
\hline Myristic, 14:0 & $0,31 \pm 0,020$ & $0,23 \pm 0,014^{*}$ & $0,20 \pm 0,014^{* *}$ \\
\hline Pentadecanoic, $15: 0$ & $0,12 \pm 0,011$ & $0,11 \pm 0,011$ & $0,10 \pm 0,011$ \\
\hline Palmic, $16: 0$ & $22,4 \pm 1,13$ & $21,5 \pm 1,28$ & $20,8 \pm 1,27$ \\
\hline Palmitooleic, $16: 1$ & $0,31 \pm 0,020$ & $0,39 \pm 0,017^{*}$ & $0,42 \pm 0,012^{* *}$ \\
\hline Stearic, $18: 0$ & $4,85 \pm 0,191$ & $4,71 \pm 0,190$ & $3,95 \pm 0,190^{*}$ \\
\hline Oleic, $18: 1$ & $16,4 \pm 0,95$ & $21,0 \pm 0,97^{*}$ & $21,9 \pm 0,70^{* *}$ \\
\hline Linoleic, $18: 2$ & $1,27 \pm 0,093$ & $1,85 \pm 0,097^{* *}$ & $2,00 \pm 0,128^{* *}$ \\
\hline Linolenic, $18: 3$ & $26,5 \pm 1,40$ & $35,3 \pm 1,47^{* *}$ & $36,0 \pm 1,39^{* *}$ \\
\hline Total concentration of fatty acids & 73,4 & 85,9 & 86,1 \\
\hline Including saturated & 28,8 & 26,9 & 25,9 \\
\hline \multicolumn{1}{|c|}{ monounsaturated } & 16,7 & 21,4 & 22,3 \\
\hline polyunsaturated & 27,8 & 37,1 & 38,0 \\
\hline n-3/n-6 & 20,9 & 19,1 & 18,0 \\
\hline
\end{tabular}

Lower quantity of nonetherified forms of saturated fatty acids in honeycombs obtained from the beehives located in the areas with medium and low technological impact in comparison with honeycombs obtained from the beehives located in the areas with high anthropogenic impact is caused by the lower content of fatty acids with even and odd number of carbon atoms in the chain in their composition.

Nonetherified forms of caprylic, caprin, lauric, oleic, linoleic and linolenic acids demonstrate the most significant antibacterial and antifungal activity (Bogdanov, 2003; Bogdanov et al., 2003). We observed that the level of the technogenic loading on the environment has a significant impact on the total concentration of nonetherified forms of caprylic, capric, lauric, oleic, linoleic and linolenic acids in honeycombs. Thus, the total content of nonetherified forms of the above- mentioned fatty acids in the honeycombs obtained from the beehives located in areas with medium and low technogenic loading compared to the honeycombs obtained from the beehives located in the areas with high anthropogenic impact increases.

Nonetherified forms of monounsaturated (oleic and palmitooleyic) and especially polyunsaturated (linoleic and linolenic) fatty acids show maximum antibacterial and antifungal activity (Pauguel et al., 1993; Manning, 2001; Bogdanov et al., 2003). We found out that the level of the technogenic loading on the environment has a significant 
impact on the overall content of nonetherified forms of monounsaturated and polyunsaturated fatty acids in the newly built honeycombs. So, the total content of nonetherified forms of monounsaturated and polyunsaturated fatty acids in the honeycombs obtained from the beehives located in the areas with medium and low technological loading in comparison with the honeycombs obtained from the beehives located in the areas with high anthropogenic impact is higher.

Nonetherified forms of long-chain fatty acids have the ability to bind heavy metals, especially divalent. At the same time, nonetherified forms of long-chain fatty acids (18 or more carbon atoms in the chain) have the highest ability to bind heavy metals (Jenkins and Palmquist, 1982; Bogdanov et al., 2005). Binding nonetherified forms of long-chain fatty acids with heavy metals takes place in the wax glands of honeybees (Saranchuk, 2013). As the result of this process anionic forms of fatty acids are formed. We found out that the level of technogenic loading on the environment affects the total content of anionic forms of fatty acids in newly built honeycombs. Thus, the total content of anionic forms of fatty acids in the newly built honeycombs obtained from the beehives located in areas with medium and low technogenic loading is lower than in the honeycombs obtained from the beehives placed in the areas with a high level of technogenic loading (Table 3).

The lower number of anionic fatty acids in the newly built honeycombs obtained from the beehives located in areas with medium and low technogenic loading in comparison with honeycombs obtained from the beehives located in the areas with high anthropogenic impact is explained by the lower content of saturated fatty acids with even and odd number of carbon atoms in the chain, monounsaturated fatty acids families n-7 and n-9 fatty acids and families of $n-3$ and $n-6$ in the composition of those honeycombs. In this case, the ratio of anionic forms of the n3 family of polyunsaturated fatty acids and anionic forms the n-6 family of polyunsaturated fatty acids is lower (Table 3).

The process of binding nonetherified forms of fatty acids with heavy metals in honeybee wax glands and the formation of anionic forms of fatty acids can be seen reflected in the content of fatty acids of total lipids in honeycombs. The latter are represented mainly by fatty acids that are found in terrestrial connection with long-chain alcohols.

Table 3

Content of anionic forms of fatty acids in honeycombs ( $\mathrm{mg} / \mathrm{kg}$ natural mass, $\mathrm{M} \pm \mathbf{m}, \mathbf{n}=\mathbf{3})$

\begin{tabular}{|l|c|c|c|}
\hline \multirow{2}{*}{ Fatty acids and their code number } & \multicolumn{2}{c|}{ Level of technogenic loading on the environment } \\
\cline { 2 - 4 } & high & middle & low \\
\hline Caprylic, $8: 0$ & $0,45 \pm 0,017$ & $0,38 \pm 0,014^{*}$ & $0,36 \pm 0,012^{* *}$ \\
\hline Capric, $10: 0$ & $0,16 \pm 0,011$ & $0,12 \pm 0,006^{*}$ & $0,11 \pm 0,006^{* *}$ \\
\hline Lauric, $12: 0$ & $0,22 \pm 0,011$ & $0,17 \pm 0,011^{*}$ & $0,16 \pm 0,006^{* *}$ \\
\hline Myristic, $14: 0$ & $0,20 \pm 0,011$ & $0,16 \pm 0,009^{*}$ & $0,15 \pm 0,010^{*}$ \\
\hline Pentadecanoic, 15:0 & $0,08 \pm 0,006$ & $0,05 \pm 0,006^{*}$ & $0,04 \pm 0,006^{* *}$ \\
\hline Palmic, 16:0 & $16,4 \pm 0,96$ & $13,3 \pm 0,58^{*}$ & $12,8 \pm 0,49^{*}$ \\
\hline Palmitooleic, $16: 1$ & $0,20 \pm 0,011$ & $0,16 \pm 0,006^{*}$ & $0,15 \pm 0,006^{* *}$ \\
\hline Stearic, 18:0 & $3,87 \pm 0,130$ & $3,44 \pm 0,087^{*}$ & $3,37 \pm 0,075^{*}$ \\
\hline Oleic, $18: 1$ & $11,1 \pm 0,73$ & $9,1 \pm 0,21^{*}$ & $8,8 \pm 0,24^{*}$ \\
\hline Linoleic, $18: 2$ & $0,87 \pm 0,037$ & $0,76 \pm 0,026$ & $0,73 \pm 0,026^{*}$ \\
\hline Linolenic, 18:3 & $18,5 \pm 1,02$ & $15,3 \pm 0,41^{*}$ & $14,8 \pm 0,46^{*}$ \\
\hline Total content of fatty acids & 52,1 & 43,0 & 41,5 \\
\hline Including saturated & 21,4 & 17,7 & 17,0 \\
\hline \multicolumn{1}{|c|}{ monounsaturated } & 11,3 & 9,2 & 9,0 \\
\hline polyunsaturated & 19,4 & 16,1 & 15,6 \\
\hline n-3/n-6 & 21,3 & 20,2 & 20,3 \\
\hline
\end{tabular}

We found out that the level of technogenic loading on the environment affects the content of fatty acids of total lipids in the newly built honeycombs. Thus, the content of fatty acids of total lipids in the newly built honeycombs obtained from beehives located in the areas with medium and low technogenic loading is higher than in the honeycombs received from the beehives placed in the area with high level of anthropogenic loading (Table 4). The higher quantity of fatty acids of total lipids in the newly built honeycombs obtained from the beehives located in areas with medium and low technogenic loading, compared with honeycombs obtained from beehives placed in areas with high anthropogenic impact is mainly due to the higher content in their composition of monounsaturated fatty acids families n-7 and n-9 fatty acids and families of $n-3$ and n- 6 . The ratio of polyunsaturated fatty acids of n-3 family to the n- 6 family of polyunsaturated fatty acids in newly built honeycombs is lower (Table 4). In the newly built honeycombs obtained from the beehives located in the areas with medium and low technogenic loading compared to the honeycombs received from the beehives located in the areas with high anthropogenic impact the concentration of the major saturated fatty acids of total lipids with even number of carbon atoms in the chain decreases.

The lower ratio of saturated fatty acids to unsaturated fatty acids of total lipids in the newly built honeycombs obtained from the beehives located in the areas with medium and low technogenic loading in comparison with the honeycombs obtained from the beehives located in the areas with high anthropogenic impact may indicate a decrease in the fragility of their walls.

Antibacterial and antifungal activity is inherent to many fatty acids - caprylic, capric, lauric, oleic, linoleic and linolenic (Lee et al., 2001; Bogdanov et al., 2003). Thus, the content of the above-mentioned acids of total lipids the newly built honeycombs obtained from the beehives located in the areas with medium and low technogenic loading compared to the honeycombs obtained from the beehives located in the areas with high anthropogenic impact is higher. The above- 
mentioned fact may indicate that antibacterial and antifungal activity of the newly built honeycombs is higher in the areas with lower levels of pollution.

The maximum antibacterial and antifungal activity is observed in monounsaturated (oleic and palmitooleic) and, especially, in polyunsaturated (linoleic and linolenic) fatty acids of total lipids (Bogdanov et al., 2003). We found out that environmental conditions have a significant environmental impact on the overall content of monounsaturated and polyunsaturated fatty acids of total lipids in the newly built honeycombs. Thus, the contents of the above-mentioned fatty acids of total lipids in the honeycombs obtained from the beehives located in the areas with medium and low technogenic loading in comparison with the honeycombs obtained from the beehives placed in the areas with high anthropogenic impact is higher.

Concentration of fatty acids of total lipids in honeycombs (mg/kg natural mass, $M \pm \mathbf{m}, \mathbf{n}=\mathbf{3})$

\begin{tabular}{|c|c|c|c|}
\hline \multirow{2}{*}{ Fatty acids and their code number } & \multicolumn{3}{|c|}{ Level of technogenic loading on the environment } \\
\hline & high & middle & low \\
\hline Caprylic, 8:0 & $5,47 \pm 0,229$ & $4,33 \pm 0,177 * *$ & $3,67 \pm 0,133 * * *$ \\
\hline Capric, 10:0 & $2,06 \pm 0,069$ & $1,17 \pm 0,079 * * *$ & $0,71 \pm 0,040 * * *$ \\
\hline Lauric, 12:0 & $2,70 \pm 0,104$ & $1,30 \pm 0,049 * * *$ & $0,80 \pm 0,052 * * *$ \\
\hline Myristic, $14: 0$ & $2,87 \pm 0,075$ & $2,02 \pm 0,102 * * *$ & $1,46 \pm 0,066^{* * *}$ \\
\hline Pentadecanoic, 15:0 & $1,02 \pm 0,006$ & $1,24 \pm 0,003 * * *$ & $1,30 \pm 0,003 * * *$ \\
\hline Palmic, 16:0 & $193,6 \pm 5,8$ & $190,6 \pm 5,5$ & $188,1 \pm 5,5$ \\
\hline Palmitooleic, $16: 1$ & $2,70 \pm 0,052$ & $3,19 \pm 0,133^{*}$ & $4,99 \pm 0,095 * * *$ \\
\hline Stearic, 18:0 & $43,7 \pm 0,94$ & $39,7 \pm 0,68^{*}$ & $38,9 \pm 0,73 * *$ \\
\hline Oleic, $18: 1$ & $139,7 \pm 1,68$ & $146,7 \pm 1,93^{*}$ & $164,7 \pm 1,96^{* * *}$ \\
\hline Linoleic, 18:2 & $10,1 \pm 0,60$ & $13,3 \pm 0,51$ & $17,2 \pm 0,51^{* * *}$ \\
\hline Linolenic, 18:3 & $228,6 \pm 3,5$ & $239,4 \pm 2,1^{*}$ & $252,0 \pm 2,3^{* *}$ \\
\hline Total content of fatty acids & 632,6 & 642,8 & 673,8 \\
\hline Including saturated & 251,4 & 240,3 & 234,9 \\
\hline monounsaturated & 142,4 & 149,8 & 169,7 \\
\hline polyunsaturated & 238,8 & 252,7 & 269,2 \\
\hline$n-3 / n-6$ & 22,5 & 18,0 & 14,6 \\
\hline
\end{tabular}

Long-chain fatty acids (18 or more carbon atoms in the chain) in the honeycombs can bind heavy mineral elements, especially divalent (Jenkins and Palmquist, 1982; Suárez et al., 1996; Bogdanov et al., 2005). We observed that the ecological conditions of the environment influence the content of the above-mentioned fatty acids of total lipids in the newly built honeycombs. Therefore, the content of long-chain fatty acids of total lipids in the honeycombs obtained from the beehives located in the areas with medium and low technogenic loading compared to the honeycombs obtained from the beehives placed in the areas with high anthropogenic impact is higher.

As a result, the newly built honeycombs obtained from the beehives located in the areas with middle- and low technogenic loading contain fewer heavy metals. At the same time, in the honeycombs obtained from the beehives located in the areas with medium and low technogenic loading the content of anionic forms of fatty acids is lower, but the content of nonetherified acids is higher. These combs also contain a higher amount of fatty acids of total lipids. The newly built honeycombs in the areas with low technogenic loading undergo the largest changes in concentration of heavy metals, nonetherified and anionic forms of fatty acids and fatty acids of total lipids.

\section{Conclusions}

The newly built honeycombs obtained from the beehives located in the areas with middle-and low technogenic loading contain smaller amounts of iron, zinc, copper, chromium, nickel, lead and cadmium.

The newly built honeycombs obtained from the beehives located in the areas with medium and low technogenic loading havea lower content of anionic forms of saturated fatty acids with even and odd number of carbon atoms in the chain, monounsaturated fatty acids of n-7 and n-9 families and polyunsaturated fatty acids of n-3 and n-6 families.

The newly built honeycombs obtained from the beehives located in the areas with medium and low technogenic loading contain more nonetherified forms of monounsaturated fatty acids of $n-7$ and n-9 families, and polyunsaturated fatty acids of $n-3$ and $n-6$ families. Due to the above-mentioned monounsaturated and polyunsaturated fatty acids the number of fatty acids of total lipids in them is higher.

The largest changes in concentration of heavy metals, nonetherified and anionic forms of fatty acids and fatty acids of total lipids take place in the newly built honeycombs in the areas with low technogenic loading.

Prospects for further research. It is necessary to study the content of heavy metals and fatty acids in bee pollen and ambrosia.

\section{References}

Bogdanov, G.O., Polishchuk, V.P., Rivis, J.F., Lokutova, O.A., 2003. Fatty acids of plant pollen (bee pollen) and their role in metabolic processes and bee life. The Animal Biology 5, 149-158 (in Ukrainian).

Bogdanov, G.O., Polishchuk, V.P., Rivis, J.F., Lokutova, O.A., 2005. Biological evaluation of bee pollen. Naukovyi Visnyk Lvivskoi Natsionalnoi Akademii Veterynarnoi Medytsyny imeni S.Z. Gzhytskoho 7(2), 227-239 (in Ukrainian).

Bogdanov, S., 2003. Quality and standards of pollen and beeswax. Apiacta 38(4), 334-341.

Bogdanov, S., 2006. Contaminants of bee products. Apidologie 37(1), 1-18. 
Brygadyrenko, V., Ivanyshyn, V., 2015. Changes in the body mass of Megaphyllum kievense (Diplopoda, Julidae) and the granulometric composition of leaf litter subject to different concentrations of copper. J. Forest Sci. 61(9), 369-376.

Brygadyrenko, V.V., Ivanyshyn, V.M., 2014. Vlijanie soli zheleza na massu tela Megaphyllum kievense (Diplopoda, Julidae) i granulometricheskij sostav podstilki v laboratornom jeksperimente [Impact of ferric salt on body weight of Megaphyllum kievense (Diplopoda, Julidae) and litter granulometric composition in the laboratory experiment]. Visn. Dnìpropetr. Unìv. Ser. Bìol. Ekol. 22(1), 83-87 (in Russian).

Buchwald, R., Breed, M.D., Bjostad, L., Hibbard, B.E., Greenberg, A.R., 2009. The role of fatty acids in the mechanical properties of beeswax. Apidologie 40(5), 585-594.

Conti, M.E., Botrè, F., 2001. Honeybees and their products as potential bioindicators of heavy metals contamination. Environ. Monit. Assess. 69(3), 267-282.

Haiyan, W., Stuanes, A., 2003. Heavy metal pollution in airwater-soil-plant system of Zhuzhou city, Hunan province, China. Water Air Soil Poll. 147, 79-107.

Jenkins, T.C., Palmquist, D.L., 1982. Effect of added fat and calcium on in vitro formation of insoluble fatty acid soaps and cell wall digestibility. J. Anim. Sci. 55, 957-963.

Khavezov, I., Tsalev, D., 1983. Atomno-absorbtsionnyi analiz [Atomic absorption analysis]. Chemistry, Leningrad (in Russian).

Kononskyy, O.I., 2006. Biokhimiia tvaryn [Biochemistry of the animals]. Vyshcha Shkola, Kyiv (in Ukrainian).

Kulbachko, Y., Loza, I., Pakhomov, O., Didur, O., 2011. The zoological remediation of technogen faulted soil in the industrial region of the Ukraine Steppe zone. In: Behnassi, M. et al. (eds.), Sustainable agricultural development. Springer Science + Business Media, Dordrecht, Heidelberg, London, New York, 115-123.

Lee, J.Y., Sohn, K.H., Rhee, S.H., Hwang, D., 2001. Saturated fatty acids, but not unsaturated fatty acids, induce the expression of cyclooxygenase- 2 mediated through Toll-like receptors 4. J. Biol. Chem. 276, 16683-16689.

Loidl, A., Crailsheim, K., 2001. Free fatty acids digested from pollen and triolein in the honeybee (Apis mellifera carnica Pollmann) midgut. J. Comp. Physiol. B 171(4), 313-321.

Manning, R., 2001. Fatty acids in pollen: A review of their importance for honey bees. Bee World 82(2), 60-75.

Pashayan, S.A., 2006. Svoystva migratsii tyazhelyih metallov [Properties of heavy metal migration]. Pchelovodstvo Beekeeping 9, 12-13 (in Russian).
Pauguel, S.C., Bert, M., Dolley, S., 1993. Antimicrobial activity of pollen. Phytochemistry 33(6), 2503-2507.

Perugini, M., Manera, M., Grotta, L., Abete, M.C., Tarasco, R., 2011. Heavy metal $(\mathrm{Hg}, \mathrm{Cr}, \mathrm{Cd}$, and $\mathrm{Pb})$ contamination in urban areas and wildlife reserves: Honeybees as bioindicators. Biol. Trace Elem. Res. 140(2), 170-176.

Rivis, J.F., Fedoruk, R.S., 2010. Kil'kisni khromatohrafichni metody vyznachennya okremykh lipidiv i zhyrnykh kyslot $u$ biolohichnomu materiali [Quantitative chromatographic methods for determination of individual lipids and fatty acids in biological material]. Spolom, Lviv (in Ukrainian).

Saranchuk, I.I., 2013. Kontsentratsiia riznykh form zhyrnykh kyslot $\mathrm{u}$ tkanynakh cherevtsia medonosnykh bdzhil zalezhno vid ekolohichnykh umov dovkillia [Concentration of different forms fatty acids in the tissues of the abdomen of melliferous bees depending on the ecological conditions of the environment]. Scientific Journal Askania-Nova 6, 251-257 (in Ukrainian).

Suárez, A., Faus, M.J., Gil, A., 1996. Dietary long-chain polyunsaturated fatty acids modify heart, kidney, and lung fatty acid composition in weanling rats. Lipids 31(3), 345-348.

Tan, K., Liu, X., Dong, S., Wang, C., Oldroyd, B.P., 2015. Pheromones affecting ovary activation and ovariole loss in the Asian honey bee Apis cerana. J. Insect Physiol. 74, 25-29.

Tsvetkova, N.M., Pakhomov, O.Y., Serdyuk, S.M., Yakyba, M.S., 2016. Biologichne riznomanittja Ukrajiny. Dnipropetrovs'ka oblast'. Grunty. Metaly u gruntah [Biological diversity of Ukraine. The Dnipropetrovsk region. Soils. Metalls in the soils]. Lira, Dnipropetrovsk (in Ukrainian).

Vikram Reddy, M., Satpathy, D., Dhiviya, K.S., 2013. Assessment of heavy metals $(\mathrm{Cd}$ and $\mathrm{Pb})$ and micronutrients $(\mathrm{Cu}$, $\mathrm{Mn}$, and $\mathrm{Zn}$ ) of paddy (Oryza sativa L.) field surface soil and water in a predominantly paddy-cultivated area at Puducherry (Pondicherry, India), and effects of the agricultural runoff on the elemental concentrations of a receiving rivulet. Environ. Monit. Assess. 185(8), 6693-6704.

Vymazal, J., Březinova, T., 2016. Accumulation of heavy metals in aboveground biomass of Phragmites australis in horizontal flow constructed wetlands for wastewater treatment: A review. Chemical Engineering Journal 290, 232-242.

Надійшла до редколегї 10.02.2016 